more abundant are normoblasts, megaloblasts and other abnormal red cells in the peripheral circulation.

8. Neither Carrion's fever nor verruga eruption can be produced in either man or laboratory animals by the injection of blood containing the Bartonia bodies alone, but both can be produced in man by injection of the virus from the human eruption, and the benign form can be produced in laboratory animals by such injection, the reason why the acute form has not been similarly produced being that either the animals are far less susceptible to the disease than man or the toxicity of the virus becomes attenuated for them after running its course in man, though experience indicates that it may yet be so produced in monkeys if not in other animals.

9. The pathologic microorganisms transmitted by Phlebotomus in all parts of the world so far as known invariably set up an initial fever stage of longer or shorter duration and greater or less intensity, and verruga eruption is in every case preceded by some degree of pyrexia, though sometimes so slight as to be hardly noticeable.

10. The eruption following Carrion's fever as well as the eruption preceded by mild fever or an almost unappreciable degree of fever both show a marked tendency to appear first at the sites of inoculation by the Phlebotomus and to become most pronounced at such sites.

11. Cases of eruption following either often if not always confer immunity against both.

12. Phlebotomus verrucarum gets its infection certainly from some reservoir, probably one of the native mammals, but whether from the lower mammals or man it is practically certain that the reservoir of infection supplies but one kind of microbe capable of developing in and being transmitted by the carrier.

13. Both are amenable to the same treatment so far as this has been determined for either.

All of the above facts have been verified by the writer's work and experience during his investigation of verruga transmission in the verruga zones and in the laboratory. Severe pyrexia has resulted in a Cebus capuchinus from the bites of the Phlebotomus, the rectal temperature passing $43^{\circ} \mathrm{C}$. and the red cells showing the Bartonia bodies. Miliar eruption succeeded. The Bartonia bodies have also been found by the writer in the red cells of $\mathrm{dog}$, rabbit and guinea-pig inoculated with the Phlebotomus. Eruption away from site of inoculation has been produced in a hairless dog by hypodermic injection of over 400 Phlebotomus in five lots, mashed up in physiological solution. Upon the excision of a large nodule, another has grown in its place. The writer's assistant in the verruga work, Mr. George E. Nicholson, is in the hospital with verruga, the result of 55 bites by Phlebotomus September 17 last at Verrugas Canyon, due to inadvertently getting his hands in contact with the net while asleep. His symptoms have been high fever with severe bone pains, and a large number of Bartonia bodies in the red cells. Details of the experiments with laboratory animals will shortly be presented, including blood and tissue studies, temperatures and weights, with illustrations.

Almost any one of the above reasons, taken by itself, would seem to indicate conclusively the unity of verruga. If Dr. Strong's thesis can be made to harmonize with all of these facts, then it is possible that he is right, but the indications seem to point strongly the other way. Charles H. T. Townsend

VERRUGA LABORATORY, Chosica, Peru,

November 17,1913

SCIENTIFIC BOOKS

Scott's Last Expedition. Vol. I., being the Journals of Captain R. F. ScotT, R.N., C.V.O. Vol. II., being the Reports of the Journeys and the Scientific Work undertaken by Dr. E. A. Wilson and the surviving members of the Expedition. Arranged by Leonard Hexley, with a preface by Sir Clements R. MarkhaM, K.C.B., F.R.S. With 18 colored plates, 260 full-page and smaller illustrations. New York. Dodd, Mead and Company, 1913. Large 8vo. 2 vols. $\mathrm{xxiv}+443$, xiv +376 pp. 8 maps. $\$ 10.00$ net. 
It is many years, if ever, since the civilized world has been so stirred into homage to courage and to sympathy for disaster, as were displayed when the ocean cables spread over the globe the fateful story of Scott's Last Expedition, which is now told in these beautiful volumes. Suffice it to say that the detailed record shows high planes of project and of action, which should ensure to Commander Evans and his surviving associates scarcely less honor and credit than is given so fittingly to Scott and his heroic dead.

That recognized polar authority. Sir Clements R. Markham, outlines the ains and scope of Scott's expedition as the "completion and extension of his former discoveries," especially of "fossils, which would throw light on the former history of the great mountains," which bound the south-polar plateau. For this work Scott had " the most completely equipped expedition for scientific purposes connected with the polar regions. both as regards men and material," and " a fuller complement of geologists, biologists, physicists and surveyors than ever before composed the staft of a polar expedition." Science was the primary aim, so that Scott had removed the taint of commercialism, which caused Milton to qualify his praise of the quest of a northern route to China by saying it "might have seemed almost heroic if any higher end than excessive love of gain and traffic had animated the design." Thus a twentieth-century sailor attained the seventeenth century ideal of heroism.

Referring briefly to the south-polar journey, it is clear that Scott's plans were perfected and carried out with striking ability. Despite a season of unprecedented severity as to blizzards and cold, the party would have survived but for other misfortunes. These were the inability to originally occupy Cape Crozier as a base, owing to ice-conditions; the breakdown and loss of motor sledges; and especially the deep, soft snow that fell during the four-day blizzard at Beardmore glacier on the outward journey. Later came the death of Evans from crevasse-injuries and sastrugi-falls, and the freezing of heroic Oates, which followed close on the time lost and delays caused by geologi- cal work, a primary aim be it remembered. Let the readers of Science bear in mind that these men perished indirectly as martyrs to a sense of scientific duty. The day spent in collecting the fossil volumes that may tell the story of past geological history, and the strength consumed in dragging these specimens, nearly forty pounds in weight, exhausted the fatal limit of time and so sealed their fate. Yet no word is uttered suggestive of abandoning their harrowing load, over frightful mazes of sastrugi and of glacier.

This is not the place to dwell on the ideals of courage, of devotion, of unselfishness, which ran like the King's red thread through the warp and woof of their expeditionary dutiesof the living as well of the dead. Their recital moves the hearts of the present, and will serve as examplars to stir the souls of the future.

Storm-bound and crevasse-injured, the southern party perished to a man within eleven miles of safety, while ending a sledge journey of more than sixteen hundred miles,unprecedented for its length in polar annals. As to conditions which prevented that short march to food and fuel, they had for the ten previous days traveled in temperatures averaging sixty-eight degrees below freezing (this in March. our September), and were enveloped in a blinding blizzard, which lasted continuously for eight days.

In these transcripts from Scott's diary are no words of adverse criticism when he received the astounding news that a rival was in the field,-for south-polar travel only be it noted. Anuundsen's route being shorter, foreseeing the probability of being forestalled at the pole, Scott recalls with becoming dignity of soul the scientific scope of his work in the sober statement, on September 10, 1911, that " nothing, not even the priority at the Pole, can prevent the expedition ranking as one of the most important that ever entered the polar regions."

Severe as were the physical experiences of the south-polar party in their dramatic explorations, they entailed relatively less bodily discomfort and acute suffering than did the midwinter journey for strictly scientific pur- 
poses to the penguin rookery at Cape Crozier. The object of the trip was to secure eggs of the emperor penguin-a species most nearly approaching the primitive form of bird-at such stages of early embryos as might make clear the development of the emperors. A journey in midwinter was necessary as the singular emperor penguin is perhaps unique in nesting at the coldest season of the yearin temperatures approximating one hundred degrees below the freezing point of water.

Apart from the weather the trip involved sledge travel of two hundred miles in almost complete darkness, wherein the party must cross the crevassed "barrier" and finally pass through the chaotic pressure-ridges of the shore-impinging sea floes. The journey was made without disaster, and three eggs brought safely home, but this scientific work tested humanity to the utmost. The outward march was made in eighteen days with an average temperature of minus forty degrees-that of frozen mercury. Only once did the temperature rise to zero Fahr., and a minimum of one hundred and nine degrees below freezing was experienced. A violent blizzard, in which an hourly wind velocity of 84 miles was recorded at the home station, blew away their tent and unroofed their hut. Exposed to the fury of the storm they were forty-eight hours without food, uncertain of their fate. They finally recovered their tent, without which they must have perished, for the blizzard temperature of $+24^{\circ}$ fell steadily to $-66^{\circ}$ Fahr. For science and not for fame was made a trip unsurpassed as to the severity of cold and violence of storm successfully endured by a field party.

The scientific appendices to these volumes are brief and tentative, as would naturally be expected. Full of thrilling interest and of importance are the accounts of the journeys made for the physiographic and geological explorations of the coast regions of northeastern South Victoria Land. The enforced wintering of Campbell's party, equipped for summer travel only, was on the verge of disaster several times. Wintering in a hut carved out of a snow-covered glacier, they lived for nine months from hand to mouth on penguins and seals. Other scientists had experiences but little less dangerous and trying. Indeed it may be said that no previous polar expedition has ever surpassed that of Scott in the devotion of its staff to scientific investigations entailing personal, prolonged and perilous service.

Brief chapters treat of scientific work, such as that wonderful survival of the condition of the Ice Age-the so-called barrier of Ross; the physiography and glacial geology of South Victoria, supplemented by a geological history of that ice-clad region; fossils connected with coal-beds, and those thought to be suited to settle the controversy as to the nature of the connection of Australia and Antarctica; and as to ice physics. Meteorology, tides, magnetism, pendulum work, and atmospheric electricity are treated, though incompletely, while the local sea-work is supplemented by a summary of the biological investigations carried on by the Terra Nova in her voyages from 1910 to 1913. Volcanic investigations were pursued on Mt. Erebus, and fossil evidences were obtained from the Great Beacon Sandstone Series.

No previous volumes of polar narrative have been so fully and appropriately illustrated as this thrilling story of the work of Scott's Last Expedition, largely due to Dr. Wilson and Mr. Pointing. Not only do the illustrations please the artistic sense, but many will also be of permanent value to scientific students. This is especially true of the photographic plates showing glacial conditions, and the many beautiful reproductions of snow and ice forms. Nor can one neglect those of birds and seals, of mountains and clouds, and even of blizzards. Among the 278 full-page plates will be found some which will convey ampler and clearer ideas to experts than does the written word.

The editorial supervision must have been hasty, for there are many slips and the text is overburdened-detracting from the dignity of the narrative. The main map is most unsatisfactory. Oates Land does not appear thereon. It is an offence to Americans that not only is Wilkes Land omitted from the kev map, but it 
has been replaced by King George V. Land; patriotic but a sad blunder.

The appreciation accorded to the Scott expedition excites reflections as to the contrasting attitude of the United States and of European governments towards scientific work that is neither commercialized nor exploited. Strikingly similar in aims, in accomplishment and in fateful disaster were the Lady Franklin Bay International Polar Expedition and Scott's Last Expedition. The former-a governmental enterprise-penuriously fitted, its scientific work largely entrusted to enlisted men-who were actuated largely by love of science-occupied the post of honor and of danger of the eleven cooperating nations. It contributed to a hitherto unequalled degree to arctic hydrography, meteorolozy, pendulum work and magnetism. Yet its complete success in its scientific purposes, as well as in field-work absolutely free from disaster, was formally requited neither by the government nor by any scientific societies of the United States. It took years of effort on the part of its chief to even obtain the meager lawful allowances and the pitiful pensions.

The English expedition, lavishly equipped, had 7 officers and 12 scientists, whose efforts also increase to a very large degree our scientific knowledge of Antarctica. Its heroic personnel win titles of nobility, promotions and the highest scientific honors, while the public contributed hundreds of thousands of dollars to meet adequately and generously all expeditionary requirements-both material and memorial.

The failure of our government to properly recognize scientific work appears to be due to an antiquated and inherited national policy, which must be to the ultimate detriment of the common weal. This year the attention of the government has been urgently called to untoward conditions, arising from illiberal treatment of expert officials. Distinguished chiefs of several important national bureaus officially report increasing difficulty in maintaining an efficient scientific staff. Unusual and steadily augmenting numbers of scientists and experts are accepting commercial posi- tions in order to meet the enhanced cost of living.

While American admiration for the Scott expedition was so great that we materially aided in the raising of the memorial fund, our energies should also be employed in urging the adequate recognition of those scientific and professional officials, on whose skill, judgment, and patriotism the future of the democratic government in the western hemisphere must so largely rest.

\section{A. W. Greely}

\section{Probleme der physiologischen und pathologi-} schen Chemie. Fünfzig Vorlesungen über neuere Ergebnisse und Richtungslinien der Forschung für Studierende, Ärzte, Biologen und Chemiker. By Dr. Otтo von Fürth. II. Band: Stoffwechsellehre. Leipzig, Verlag von F. C. W. Vogel, 1913. Pp. xiv + 717.

The only occasion for adding anything to the favorable impression of Professor von Fürth's lectures which the reviewer has already expressed ${ }^{1}$ in reference to the first volume lies in the fact that the newer collection deals with a more specific group of topics: metabolism. The author's underlying plan consists in starting with the nutrients at the very beginning of the alimentary processes and in following the foodstuffs, as far as present knowledge permits, on their travels through the organism to the places where the final derivatives disappear in the unexplored depths of intermediary metabolism. To this is added a discussion of the nature of those ultimate stages of this physiological function which are characterized by the combustion of the food fragments in the living organism. In pursuance of the foregoing scheme the chemistry and physiology of digestion and absorption are reviewed in the light of those newer contributions which take cognizance of the special conditions that pertain in the alimentary canal, with its unique innervation and secretory interrelations.

The attitude of the critic to a contribution like the present one-a book giving evidence on every page of the remarkable familiarity of 1 See Science, 1912, 